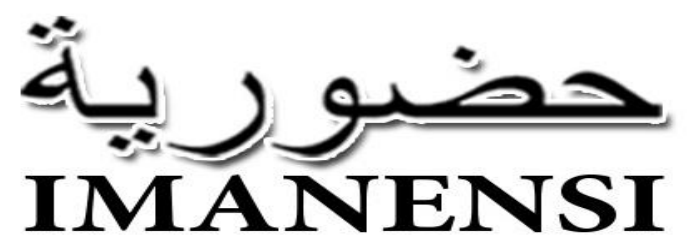

Jurnal Ekonomi, Manajemen, dan Akuntansi Islam

Vol 4, No 2, September 2019, H1mn. 44-60

\title{
Praktik jual beli kambing dengan system trade in dalam perspektif hukum islam
}

\author{
Afifatul Amaliyah ${ }^{a, 1}$, Tumirin ${ }^{\mathrm{b}, 2^{*}}$ \\ ab Univeritas Muhammadiyah Gresik, Jl. Sumatera no 101, Gresik, \\ Indonesia, 61121. \\ 1amaliyah.afifatul15321@gmail.com; 2tumirin.ms@gmail.com* \\ * penulis koresponden \\ doi $10.34202 /$ imanensi.4.2.20019.44-60.
}

\begin{abstract}
Abstrak
Tujuan dalam penelitian ini adalah untuk memahami perspektif hukum Islam terhadap praktik jual beli kambing dengan system trade in. Penelitian ini menggunakan pendekatan normatif dengan metode epistemologi bayani dan epistemologi burhani yaitu menggunakan penguasaan teks dan akal untuk menafsirkan Al-Qur'an dan as-sunnah. Hasil penelitian menunjukkan praktik jual beli kambing dengan system trade in (tukar tambah) di perbolehkan dalam sudut pandang hukum Islam, dengan syarat nilai kambing harus diketahui oleh kedua belah pihak sehingga tidak ada nilai barang yang gharar, jual beli harus diadakan kesepakatan kedua belah pihak, dan kambing yang diperjualbelikan harus kambing yang halal dan tidak cacat.
\end{abstract}

Kata kunci: Jual beli kambing; trade in; hukum Islam

\begin{abstract}
The purpose of this study is to understand the perspective of Islamic law on the practice of buying and selling goats with a system trade-in. This study uses a normative approach with the botanical epistemology bayani and the burhani epistemology, namely using mastery of the text and reason to interpret the AlQur'an, as-sunnah. The result show that the practice of buying and selling goats with a trade-in system allowed in the viewpoint of Islamic law, provided that the value of the goat must be known by both parties so that there is no value goods that gharar. and the goats that are traded must be halal and non-defective goats.
\end{abstract}

Keywords: Buying and selling goats; trade-in; Islamic law

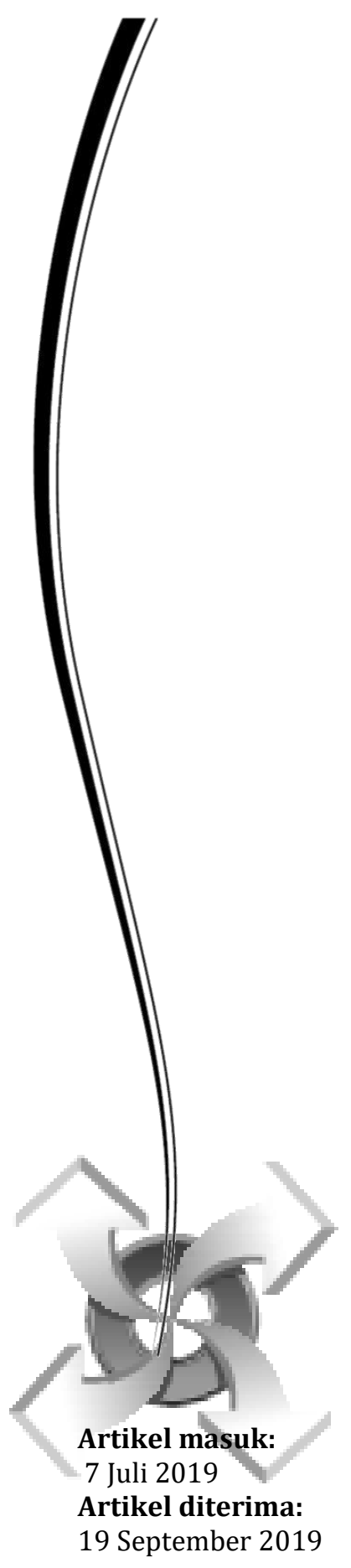




\section{PENDAHULUAN}

Jual beli merupakan suatu aktivitas ekonomi yang bisa menghasilkan keuntungan. Saat ini masyarakat mengartikan jual beli sebagai pertukaran barang dengan uang, sedangkan untuk pertukaran barang dengan barang biasa disebut dengan barter. Transaksi jual beli bisa dilakukan dengan berbagai macam cara, yaitu jual beli dengan cara tunai, kredit, bahkan saat ini banyak transaksi jual beli yang dilakukan dengan cara tukar tambah (trade in).

Transaksi jual beli menurut Syaikh Al-Qalyubi dalam bukunya Azzam (2014:24) yaitu "Akad saling mengganti dengan harta yang berakibat kepada kepemilikan terhadap satu benda atau manfaat untuk tempo waktu selamanya dan bukan untuk bertaqarrub kepada Allah." Kata "saling mengganti", maka tidak termasuk didalamnya hibah, dan yang lain yang tidak ada saling ganti, dan dengan kata "harta" tidak termasuk akad nikah sebab walaupun ada saling ganti namun ia bukan mengganti harta dengan harta akan tetapi halalnya bersenang-senang antara suami dan istri, dan dengan kata "Kepemilikan harta dan manfaatnya untuk selama-lamanya", maka tidak termasuk didalamnya akad sewa karena hak milik dalam sewa bukan kepada bendanya tapi manfaatnya.

Ada beberapa macam cara dalam melakukan transaksi jual beli, diantaranya yaitu jual beli dengan cara tunai, dengan cara kredit, dengan cara barter dan dengan cara tukar tambah (trade in). Transaksi jual beli kambing dengan system trade in (tukar tambah) saat ini banyak terjadi di masyarakat. Kambing merupakan hewan yang sering diperdagangkan oleh masyarakat, karena kambing memiliki banyak manfaat bagi manusia, baik dikonsumsi, dijadikan aqiqah atau dijadikan hewan qurban. Cara yang digunakan dalam perdagangan kambing juga bermacam-macam, dari yang penjualan tunai, kredit maupun dengan cara tukar tambah (trade in).

Jual beli dengan system trade in (tukar tabah) kalau dilihat dari sudut pandang hukum Islam sendiri mengandung banyak makna, ada yang berpendapat bahwa hukum jual beli dengan system trade in (tukar tambah) itu halal, ada yang berpendapat bahwa hukum jual beli dengan system trade in (tukar tambah) haram dilakukan, ada juga yang berpendapat tergantung dari objek yang dijadikan transaksi jual beli, apakah objek tersebut termasuk barang ribawi atau bukan. Jika objeknya termasuk barang ribawi maka hukumnya haram, tapi jika objeknya tidak termasuk barang ribawi maka transaksi dengan system trade in (tukar tambah) dihalalkan. Lalu bagaimana dengan transaksi jual beli kambing dengan system trade in (tukar tambah), apakah diperbolehkan dalam sudut pandang hukum Islam? ataukah malah diharamkan menurut sudut pandang hukum Islam? Secara kasat mata transaksi tersebut mungkin dihalalkan atau diperbolehkan. Akan tetapi untuk mengetahui lebih jelasnya maka peneliti akan melakukan penelitian lebih lanjut tentang transaksi jual beli kambing dengan system trade in (tukar tambah) dalam perspektif hukum Islam.

Salafi (2006:283) dalam bukunya menjelaskan hadist mengenai hukum jual beli dengan system trade in (tukar tambah). Hadist tersebut menjelaskan bahwa manusia tidak boleh mengerjakan transaksi jual beli benda yang mengandung unsur riba dengan jenisnya secara berlebihan, baik salah satunya lebih buruk atau lebih baik, baik ditimbang atau ditakar. Benda yang di haramkan saling berlebihan ada enam hal yaitu emas, perak, biji gandum, kurma, garam, dan jagung centel.

Adapun dalam praktiknya penulis menemukan transaksi jual beli kambing dengan system trade in (tukar tambah) di Desa Ketanen Kabupaten 
Gresik yang mana seseorang datang dengan membawa kambing ukuran sedang dengan maksud ingin membeli kambing yang ukuran besar untuk dijadikan aqiqah/qurban dengan cara pembayaran berdasarkan selisih dari dua harga kambing tersebut. (Hasil observasi, 22 September 2018). Berdasarkan hal tersebut, tujuan penelitian ini untuk memahami perspektif hukum Islam terhadap praktik jual beli kambing dengan system trade in.

\section{METODE}

Pendekatan dalam penelitian ini yaitu pendekatan normatif. Nata (2004:34-38), dalam bukunya menjelaskan pendekatan normatif merupakan suatu upaya memahami agama dengan menggunakan kerangka ilmu ketuhanan yang bertolak dari suatu keyakinan bahwa wujud empirik dari suatu keagamaan dianggap sebagai yang paling benar dibandingkan dengan yang lainnya. Pendekatan teologis ini agama dianggap sebagai kebenaran mutlak dari Tuhan, tidak ada kekurangan sedikitpun dan tampak bersikap ideal. Agama tampil menawarkan nilai-nilai kemanusiaan, kebersamaan, kesetiakawanan, tolong menolong, tenggang rasa, dan persamaan derajat dalam bidang sosial. Sedangkan agama tampil menawarkan keadilan, kebersamaan, kejujuran, dan saling menguntungkan dalam bidang ekonomi. Sedangkan metode yang digunakan dalam penelitian ini menggunakan metode bayani dan burhani, metode yang menekankan pada pengusaan teks dan kekuatan akal manusia. Dimana sebuah teks dapat dibuktikan oleh akal dan kemudian bisa ditarik sebuah kesimpulan.

Sumber data dalam penelitian ini yaitu menggunakan sumber data primer dan sumber data skunder. Data primer merupakan sumber data yang memuat data utama yaitu data yang diperoleh melalui narasumber atau informan. Sedangkan data skunder merupakan sumber data tambahan yang diambil tidak secara langsung dilapangan tetapi dari sumber yang sudah dibuat orang lain, yaitu: Al-Qur'an, Al-hadist dan kaidah fiqih. Sedangkan jenis data dalam penelitian ini yaitu data documenter dan data subyek. Data documenter diperoleh dari Ayat suci AL-Qur'an, Al-hadist, dan kaidah Fiqih, sedangkan data subyek diperoleh dari opini seorang narasumber atau informan. Metode pengumpulan data dengan cara wawancara, observasi, dan dokumentasi. Tahapan-tahapan analisis data menggunakan model Miles and Huberman diantaranya: 1) Data Reduction (Reduksi Data); 2) Data Display (Penyajian Data); 3) Conclusion Drawing / Verification

\section{HASIL DAN PEMBAHASAN}

\section{A. Epistemologi Bayani, Burhani, dan 'Irfani}

Epistemologi berasal dari kata "episteme" yang artinya mendudukkan, menempatkan, atau meletakkan. Epistemologi atau filsafat pengetahuan pada dasarnya juga merupakan suatu upaya logis untuk menimbang dan menentukan nilai psikologi pengalaman manusia dalam interaksinya dengan diri sendiri, lingkungan sosial, dan alam sekitarnya (Sudarminta, 2002:18).

Al-Jabiri (1993) dalam penelitian Ahmad (2013:4), dalam khazanah peradaban Islam mengenal epistemologi yang bertumpu pada tiga kekuatan, yaitu bayani, burhani, 'irfani. Aktivitas nalar burhani menekankan pada kekuatan argumentatif yang bertumpu pada bukti empiris. Aktivitas nalar bayani menekankan pada kerja intelektual (al-tafkiri) yang bertitik tolak pada penggalian pengetahuan dari teks. Sedangkan aktivitas nalar 'irfani 
merupakan sistem kerja untuk memperoleh pemahaman yang bertumpu pada kesucian hati dalam rangka terungkapnya realitas melalui rahasia ilahi.

Epistemologi Bayani. Makiah (2014:1) epistemologi bayani mengandung beragam arti yaitu: keseimbangan (al-waslu), keterampilan (al-fashlu), jelas dan terang (al-zhuhur wa al-wudlhuh), dan kemampuan membuat terang dan generik. epistemologi bayani muncul bukan sebagai hal yang sui generis, akan tetapi ia memiliki akar historisnya dalam sejarah budaya dan tradisi pemikiran Arab. Sebagaimana dimaksud, bahasa Arab diyakini sebagai bahasa wahyu Tuhan. Sedangkan menurut Al-Jabiri seorang pemikir maroko dalam penelitian Ridwan (2016:192) menjelaskan bahwa term al-bayan mengandung empat pengertian, yaitu: pemisahan, keterpisahan, jelas dan penjelasan. Keempat pengertian tersebut bisa dikelompokkan menjadi dua kelompok: al-bayan sebagai metodologi yang berarti pemisah dan penjelas, dan al-bayan sebagai pandangan dunia yang berarti keterpisahan dan jelas.

Nalar bayani nash (teks) menurut Lutfi (2017:106) adalah menjadi poros untuk mencapai pengetahuan. Istilah nash dalam hal ini bukan hanya terpaku pada suatu acuan dalil-dalil yang ada dalam kitab suci dan assunnah, namun istilah nash dalam hal ini mengacu pada dua hal, yakni dalil yang bersifat qat'I yang tertera dalam kedua sumber kitab, yakni Al-Qur'an dan as-sunnah dan ijtihad. Pengambilan argumen yang berbasis pada dalildalil namun dalil-dalil tersebut karena pengungkapannya masih bersifat abstrak dan belum bisa dipahami kejelasannya maka diperlukan adanya ijtihad. Oleh karena itu nash dalam pengertian ini ada dua, yakni Al-Qur'an dan as-sunnah dan ijtihad itu sendiri.

Ibrahim (2014:252-253) mengatakan metode bayani merupakan suatu metode penelitian yang diperoleh melalui usaha memahami, membaca, mempelajari, dan mengkaji penjelasan dari Al-Qur'an dan sunnah untuk mendapatkan ilmu. disamping itu, alasan lain diperlukan metode bayani adalah bahwa masing-masing teks-teks Al-Qur'an mengandung pesan-pesan yang harus diungkap secara tepat. Ungkapan dari teks-teks Al-Qur'an dan sunnah dengan metode bayani ini, pada dasarnya dapat dilakukan dengan perangkat metodologi yang telah disusun oleh para Ulama'.

Epistemologi Burhani. Makiah (2014:7) burhan secara bahasa merupakan dalih yang kuat dan jelas. Sedangkan dalam istilah logika, alburhan merupakan aktivitas intelektual untuk membuktikan kebenaran suatu asumsi melalui pendekatan deduksi dengan cara menghubungkan asumsi yang satu dengan asumsi yang telah terbukti kebenarannya. Burhan merupakan aktivitas intelektual untuk menetapkan suatu asumsi tertentu. Epistemologi burhani menggunakan aturan silogisme dalam mendapatkan pengetahuan. Silogisme merupakan suatu bentuk argumen dimana dua asumsi yang disebut premis disatukan sedemikian rupa, sehingga dapat menghasilkan sebuah keputusan (konklusi).

Lutfi (2017:100-101) sebagai sebuah episteme, bayani mengandalkan kekuatan utama yang melekat pada manusia yang disebut akal. Dengan kekuatan akal manusia yang menjadi poros utamanya, maka burhan mendefinisikan diri sebagai "al-hujjat al-fashilat al- bayyinat" (hujjat akal yang jelas dan terperinci). Sebagai sebuah kekuatan akal manusia, maka alat epistemologi burhan adalah indera, pengalaman empiris, dan hukum-hukum rasio saja dan bukan yang lainnya. Kekuatan akal manusia ini adalah satusatunya otoritas kaum burhan dalam membangun pengetahuan. Sedangkan makna selaras dengan hukum-hukum rasio adalah sebanding dengan ilmu logika, karena bagi golongan burhan, logika merupakan alat akal supaya akal tidak tergelincir dalam kesalahan berfikir, sebagaimana alat bahasa yang 
digunakan manusia supaya tidak tergelincir dalam kesalahan pengucapan dan kata-kata adalah ilmu gramatika bahasa.

Metode burhani menurut Ibrahim (2014:255) merupakan suatu metode penelitian yang mengandalkan kemampuan berfikir logis, dengan menggunakan prinsip-prinsip tertentu yang disusun secara selaras dan teratur. Metode ini dilakukan untuk memahami suatu topik ilmu yang nonfisik. Oleh karena itu dalam metode penelitian ini akal sangat berperan.

Epistemologi 'Irfani. Ridwan (2016:201) 'irfani dalam bahasa Arab merupakan masdar dari 'arafa yang semakna dengan ma'rifah. Sedangkan dikalangan para sufi, kata 'irfan dipergunakan untuk menunjukkan jenis pengetahuan yang tertinggi, yang dihadirkan dalam hati secara ilhami. Sedangkan arti kata ma'rifah dikalangan para sufi adalah sebagai pengetahuan langsung dari Tuhan berdasarkan atas wahyu atau petunjuk Tuhan.

Ibrahim (2014:258) metode tajribi ('irfani) merupakan suatu metode penelitian atau penemuan ilmu yang selain memerankan kemampuan berfikir logis, juga dilanjutkan dengan tindakan percobaan, pengamatan, atau bentuk-bentuk metode yang dikenal dalam metode penelitian ilmiah sekarang ini. Para ilmuwan muslim melakukan pengamatan-pengamatan terhadap objek-objek fisik, dengan memanfaatkan metode tajribi ('irfani) dengan baik dan sungguh-sungguh, contohnya kajian mendalam tentang astronomi, kedokteran, dan lain-lain.

\section{B. Deskripsi Umum Lokasi Penelitian}

Desa Ketanen merupakan desa kecil yang terletak di Kecamatan Panceng Kabupaten Gresik, Desa Ketanen terbagi menjadi 3 (tiga) Dusun diantaranya yaitu Dusun Sono, Dusun Ketanen, dan Dusun Lemah Ireng. Batas wilayah Dusun Sono dan Dusun Ketanen sangat berdekatan, akan tetapi batas wilayah Dusun Lemah Ireng dan Dusun Ketanen terpenggal oleh satu Desa, yaitu Desa Pantenan. Sedangkan batas wilayah Desa Ketanen disebelah Selatannya adalah Desa Siwalan, di sebelah Barat adalah Desa Pantenan dan Desa Bluri, di seblah Utara adalah Desa Prupuh, dan di sebelah Timur adalah Desa Serah dan Sirowiti, dari keseluruhan batas wilayah yang ada di Barat dan Timur merupakan batas dari persawahan, sedangkan batas wilayah yang ada di Utara merupakan batas dari Perhutanan. Desa Ketanen merupakan wilayah yang dikelilingi oleh sawah dan Desa serta letaknya berada ditengahtengah, wilayah Ketanen lebih luas di pertanian dan perkebunan daripada pemukiman penduduknya.

Mata pencaharian penduduk Desa Ketanen rata-rata banyak yang menjadi petani dan pengembala, karena dapat dilihat bahwa lahan persawahan yang dimiliki warga Desa Ketanen sangat luas, dan hewan yang dipelihara penduduk Desa juga sangat banyak diantaranya yaitu sapi, kambing, dan ayam. Selain itu juga ada banyak penduduk Desa Ketanen yang memutuskan untuk pergi ke luar negri atau menjadi tenaga buruh Migran Internasional, karena mereka mempertimbangkan skill atau kemampuan mereka yang rendah yang mana mereka hanya mengandalkan otot untuk bekerja. Namun saat ini masih ada sebagian penduduk Desa Ketanen yang bekerja sebagai wiraswasta, peternak, dan Pegawai Negeri Sipil.

\section{Praktik Jual Beli Kambing dengan System Trade In}

Fenomena yang terjadi di masyarakat, terutama di Desa Ketanen saat ini adalah jual beli kambing dengan system trade in (tukar tambah). Jual beli kambing dengan system trade in yaitu pertukaran antara dua kambing yang 
kwalitasnya berbeda, yang nantinya saat melakukan transaksi akan ada selisih harga dari kedua kambing yang di tukarkan, dan selisih tersebut harus di bayar oleh pemilik kambing yang nilainya lebih rendah. Motivasi dalam melakukan transaksi jual beli kambing dengan system trade in juga bermacam-macam diantaranya: ada yang ingin menukarkan karena ingin digunakan untuk aqiqah, ada yang ingin menukarkannya karena ingin digunakan untuk kurban, dan ada juga yang menukarkannya karena ingin investasi/menabung, kata sebagian penduduk Desa Ketanen "Ngrawati kewan iku podo koyok nabung, kewane kan pasti jangkrak, na engko lek wes gede lek gak duwe duwek karek $d$ idol, engko lek misal anak.e elek na duwe duwek yo ngomong bakul.e jalok tukar tambah cek oleh cilik seng apik, lek apik kan lek wes gede regane larang" atau istilahnya "Memelihara hewan itu sama kayak menabung, hewan kan pasti beranak dan bertambah banyak, nanti kalau udah besar dan pas nggak punya uang ya tinggal di jual saja, nanti kalau misal anak kambingnya jelek terus pas ada uang ya tinggal minta tolong ke pedagang kambing minta carikan kambing kecil yang bagus, kalau baguskan nanti pas sudah besar harga jualnya juga lebih mahal". Menurut bapak Suyakip:

"Jual beli tukar tambah iku praktek'e iku biasae iku ndelok kondisi fisik.e kambinge mau, kadang iku onok fisik.e kambinge kurang apik terus engko tukar seng apik kadangkan engko iso tambah."

"Jual beli tukar tambah itu praktiknya biasanya dilihat dari kondisi fisik kambing, kadang ada fisik kambing yang kurang bagus ditukar dengan yang bagus nanti selisihnya harganya bisa ditambah."

Jadi harga jual kambing domba itu biasanya dilihat dari ekornya, kalau ekor kambingnya kecil ya harganya murah, tapi kalau ekornya besar ya harga kambingnya lebih mahal. Kisaran harganya itu kurang lebih Rp500.000, kalau kambing besar yang ekornya kecil kalau dijual itu harganya sekitar Rp1.500.000, tapi kalau kambing besar yang ekornya besar kalau dijual itu harganya bisa sampai Rp2.000.000 bahkan bisa lebih dari Rp2.000.000. Seperti yang diungkap oleh Bapak K:

"Kambing domba iku di delok teko postur tubuhe, ekore, punggunge. Tapi lek kambing jowo, etawa iku gak iso didelok teko punggunge, tapi didelok teko dowo gak'e kupinge, dowo gak.e postur tubuhe, pasungan kepalae."

"Kambing domba itu dilihat dari postur tubuhnya, ekornya, dan punggungnya. Tapi kalau kambing jawa, etawa itu gak bisa dilihat dari punggungnya, tapi dilihat dari panjang pendeknya telinga, panjang pendeknya postur tubuh, dan pasungan di kepalanya."

Kwalitas kambing mempengaruhi harga yang telah diungkapkan oleh Bapak K sependapat dengan kwalitas kambing yang diungkap oleh Bapak $\mathrm{R}$ dan Bapak Suyakip, bahwa kwalitas kambing yang dapat memperngaruhi dapat dilihat dari jenisnya, jika kambing itu jenisnya domba maka kwalitas yang mempengaruhi adalah warna, postur tubuh, kesehatan, ekor, dan punggung. Sedangkan jika jenis kambingnya kambing jawa atau etawa maka kwalitas kambing yang dapat mempengaruhi harga adalah dilihat dari warna, telinga, postur tubuh dan pasungan kepala. Adapun saat melakukan diskusi peneliti menanyakan harga seekor kambing domba yang ukurannya cukup besar, ekornya besar, dan postur tubuhnya bagus. Saat peneliti menanyakan harga kepada ketiga informan yaitu Bapak K, Bapak R, dan Bapak Suyakip, 
ternyata yang diungkapkan oleh ketiga informan tersebut sependapat bahwa jika kambing itu laki-laki maka harganya kisaran Rp2.000.000 Rp2.500.000, tapi jika kambing itu perempuan maka harganya kisaran Rp1.000.000 - Rp1.500.000.

Setelah peneliti melakukan transaksi jual beli kambing dengan system trade in, peneliti baru menyadari ternyata di masyarakat sudah banyak yang melakukan transaksi semacam itu, ternyata jual beli dengan system trade in tidak hanya berlaku untuk emas, perak, mobil, motor, dan hp saja yang saat ini banyak terjadi dimasyarakat, tapi ternyata jual beli hewan juga bisa dilakukan dengan system trade in. Jadi jual beli dengan system trade in hampir sama dengan system barter, bedanya kalau barter kan barang dengan barang yang nilainya sejenis, tapi kalau tarde in kan ada selisih harga yang harus ditambahkan. Seperti yang dikatakan oleh bapak Dian Berkah:

"Jadi gini, yang jelas kalau kita melihat perdagangan dalam Islam sudah pasti kita mengenal istilah yang namanya barter, kalau barter nilai A dengan nilai $\mathrm{B}$ dia sama, nah dalam perjalanan kita sudah tidak sebarter, sistem jual beli antara barang dengan uang. Nah sekarang harus digabung barternya ada uangnya ada. Contoh misalnya, saya pengen menukar kambing saya dengan kambing yang B, nah B itu setelah saya hitung nilainya Rp2.000.000, kambing saya nilainya Rp1.500.000, nah biar dia unsurnya sama maka saya tambah Rp500.000, jadi biar Rp2.000.000 - Rp2.000.000.”

Transaksi jual beli kambing di masyarakat Desa Ketanen kebanyakan mereka tidak terjun langsung di pasar hewan, tapi kebanyakan meminta bantuan oleh pedagang kambing yang sekaliagus penyalur jual beli atau bakul kambing, kalau misal hewan peliharaan yang di minta oleh penduduk tidak sesuai dengan yang pedagang punya, maka biasanya kambing yang mau di tukarkan di bawah dulu oleh pedagang untuk dibawah ke pasar hewan dan di lakukan transaksi jual beli dengan system trade in di pasar hewan. Seperti yang diungkapkan oleh bapak Suyakip:

"Tergantung...tergantung perjanjian'e kadang yo onok seng digowo disek teros egko nek wes payu di olehno maneh engko karek tambah piro. Kadang yo langsung engko, karek langsung tambah piro ngunu."

“Tergantung, tergantung dari perjanjiannya, kadang ada yang di bawa dulu kambingnya baru nanti kalau sudah laku baru di belikan kambing yang diinginkan pembeli, nanti tinggal bayar kekurangannya. Kadang ya langsung tukar tambah nanti, tinggal nambah kekurangannya."

Semua transaksi jual beli harus ada perjanjiannya atau biasa di sebut dengan akad, dengan adanya akad seorang pembeli dan penjual saling mengikat antara satu dan yang lain, bahwa mereka saling menerima pertukaran itu dan tidak ada pihak yang merasa dirugikan. Menurut Muhammad Abu Zahra dalam bukunya Muslich (2013:109) akad menurut etimologi diartikan untuk menggabungkan antara ujung sesuatu dan mengikatnya, lawannya adalah "al-hillu" (melepaskan), juga diartikan mengokohkan sesuatu dan memperkuatnya. Sedangkan menurut Kitab Undang-Undang Hukum Perdata Islam, Pasal 103, yang berbunyi: Al-'Aqdu adalah perikatan di antara dua pihak dan berjanji untuk melaksanakannya, dan aqad itu gabungan antara ijab dan qabul. 


\section{Tinjauan Hukum Islam Terhadap Transaksi Jual Beli dengan System Trade In}

Hukum Islam merupakan aturan-aturan atau perintah dan larangan dari Allah SWT yang sudah tertuliskan dalam Al-Qur'an dan As-sunnah, yaitu aturan yang mengatur hubungan antara manusia dengan Tuhannya, manusia dengan manusia yang lain, dan antara manusia dengan alam sekitarnya, semuanya sudah diatur dengan sangat baik oleh Allah SWT dalam hukum Islam, seperti yang sudah di jelaskan pada QS. Al-Hujurat ayat 10-12, QS. AlBaqarah ayat 213 dan 143, QS. Sad ayat 27, QS. Yasin ayat 43, QS. Ad-Duha ayat 38, dan QS. An-Nahl ayat 5 dan 81. Menurut Shobirin (2016:240) AlQur'an dan hadist merupakan sumber hukum Islam yang banyak memberikan contoh atau mengatur bisnis yang benar menurt Islam, tidak hanya untuk penjual saja tetapi juga untuk pembeli, saat ini penjual banyak yang lebih mengutamakan keuntungan individu tanpa berpedoman pada ketentuan-ketentuan hukum Islam. Mereka hanya mencari keuntungan duniawi saja tanpa mengharapkan barokah kerja dari apa yang sudah dikerjakan. Sedangkan menurut bapak Dian:

"Yang jelas semua ditetapkan secara umum kalau kita mau kembali kepada proses bisnis kembali pada ayat "Wa-ahalla allahu albay'a waharrama alrriba" agar dia nggak riba maka ditarik kepada jual beli, maka muncul akad, Nah jadikan nanti dia jual beli barter jadikan akad ada perjanjian, akad itu betul-betul "ini kita sudah jual loh ya dengan barter"."

Riba merupakan tambahan yang disyaratkan oleh seseorang tanpa adanya usnur hadiah. Misalnya seseorang meminjam uang Rp100.000, tetapi saat perjanjian orang yang meminjamkan uang memberi syarat bahwa kembalinya harus Rp150.000, maka kelebihan uang Rp50.000 adalah riba. Kecuali jika tanpa di syaratkan, atau di ucapkan pada saat perjanjian dan ternyata yang meminjam uang memberi kelebihan Rp50.000 dengan maksud memberi hadiah kepada yang telah menolongnya maka uang tersebut tidak termasuk uang riba. Azzam (2014:216) riba merupakan akad untuk satu ganti khusus tanpa diketahui perbandingannya dalam penilaian syariat ketika berakad atau bersama dengan mengakhirkan kedua ganti atau salah satunya.

Adapun syarat-syarat yang harus diperhatikan dalam transaksi jual beli, diantaranya yaitu: (1) Syarat in'igad (terjadinya akad), (2) Syarat sahnya jual beli, (3) Syarat kelangsungan jual beli (syarat nafadz), (4) Syarat mengikat jual beli (syarat luzum). Jadi dalam melakukan transaksi jual beli yang benarbenar harus diperhatikan adalah syarat-syarat dari jual beli, supaya transaksi jual beli yang dilakukan tidak termasuk dalam transaksi jual beli yang diharamkan. Seperti yang dikatakan oleh bapak Dian Berkah mengenai salah satu syarat jual beli yaitu sebagai berikut:

"Syaratnya kalau kita jual beli dalam syariah itu kan pasti (1) barangnya tidak boleh gharar, gharar itu barangnya tidak ada kejelasan, jenis, status, perolehan kan gitu, (2) barang itu dipastikan halal yah, halal itu berarti nggak gharar, tidak maisir, tidak dijadikan sebagai obyek judi kan gitu, kemudian ya haramlah, bukan barang yang haram. Jadi Maghrib dek, maisir, kemudian haram, gharar, gitu kan ya. Makanya tadi salah satu syarat dari jual beli ya barangnya harus halal. Halal berarti apa? Ya tidak gharar, tidak haram kan gitu kan, kemudian tidak maisir, dan dijadikan sebagai obyek untuk judi, bisa juga misalnya barang-barang yang bukan diperuntukkan sesembahan kan ada kadang-kadangkan kambing untuk sesembahan 
tiba-tiba kemudian nggak diketahui dijadikan obyek untuk jual beli kan nggak boleh itu, nah itu, itu makna dari halal tadi itu ya, kemudian tidak cacat, (3) harus betul-betul diadakan kesepakatan, (4) ijab dan qabul, nah diantara kedua belah pihak antara penjual dan pembeli mereka betul-betul mengetahui kadar nilai dari kambing itu."

Adapula hadist yang menjelaskan mengenai tukar tambah kurma, yaitu "Ada seorang amil zakat yang diangkat nabi untuk Daerah Khaibar dan orang itu menukarkan kurma yang bagus satu sa' dengan dua sa' kurma yang tidak bagus, dan nabi melarang transaksi semacam ini, nabi Muhammad Saw menyuruh seorang amil zakat tersebut menjualnya dulu kurma yang kurang bagus dengan dirham, baru kemudian membeli kurma yang bagus itu dengan dirham hasil penjualnnya (Salafi, 2006:283). Hadist tersebut menjelaskan bahwa transaksi jual beli kurma dengan cara tukar tambah tidak diperbolehkan, kecuali jika pada saat melakukan transaksi yang pertama kurmanya ditukar dengan dirham dulu barulah membeli kurma yang bagus dengan dirham. Sedangkan menurut informan transaksi jual beli kurma tidak sama dengan transaksi jual beli kambing, karena kurma ada istilah bagus dan tidak bagus, sedangkan kambing tidak ada istilah tidak bagus. Berikut adalah pernyataan dari bapak Dian:

"Tukar tambah yang nilainya tidak sejenis, yah jadi itu kan kurma yang tidak bagus lah kalau ini kan kambing bukan nggak bagus. Barang itu gharar makanya nggak boleh, harus nilai yang kurma itu yang nilainya super ya ditukar dengan yang super. Kalau dia nilainya super satu nggak super ya harus menambah kekurangannya, makanya tadi kambing itu boleh menambah, ya memang harus begitu, bukan boleh harus menambah agar nilai kambing itu sama. Jadi tidak harus menguangkan, yang jelas betul-betul nilai kambing itu diketahui sama-sama, nah oleh karena itu dari segi bisnis secara syariah harus betul-betul diadakan kesepakatan, jadi syaratnya jual beli kan ada ijab, ada qabul yakan? Nah diantara kedua belah pihak antara penjual dan pembeli mereka betul-betul mengetahui kadar nilai dari kambing itu, sehingga tidak ada nilai barang yang gharar namanya."

"Saya kira itu menjadi tidak apa-apa ketika unsur antara A dengan B itu kadarnya dia sama. Contoh misalnya, saya pengen menukar kambing saya dengan kambing yang B, nah B itu setelah saya hitung nilainya Rp2.000.000, kambing saya nilainya Rp1.500.000, nah biar dia unsurnya sama maka saya tambah Rp500.000, jadi biar Rp2.000.000 - Rp2.000.000. Diperbolehkan, dengan syarat barangnya itu betul-betul dia punya nilai yang sama ya, dan unsure-unsurnya memenuhi barang-barang yang tadi yang dihalalkan dijualbelikan."

Sesungguhnya Islam sangat memudahkan manusia dalam transaksi jual beli, yang terpenting adalah saat melakukan transaksi jual beli perhatikan syarat-syarat dari jual beli itu sendiri, jika transaksi jual beli kambing sudah sesuai dengan syarat jual beli maka jual belinya termasuk jual beli yang halal, tapi jika transaksi jual beli kambing tidak sesuai dengan syaratnya atau ada unsur menipu maka transaksi itu menjadi haram dilakukan. Realitanya banyak dari masyarakat melakukan transaksi jual beli yang salah itu hanya karena mereka takut dengan kerugian yang mereka dapatkan, mereka takut dengan kurangnya harta atau sedikitnya harta yang 
mereka miliki, dan ketakutan itu hanya membuat mereka kehilangan rasa kemanusian. Seperti yang dikatakan oleh bapak Dian Berkah:

"Jual beli itu sudah gampang, Allah sudah terangkan semua jelas, ngapain dibikin sulit-sulit, yang bikin sulit itu ada orang yang ingin mencari keuntungan dengan hawa nafsuh. Seperti pada surat AtTaubah ayat 24 dan ayat 34, pada ayat itu Allah sudah pesan itu, menjauhkan kamu, membuat kamu enggan di jalan Allah, terlena terhadap bisnis, anda mencari keuntungan tidak memperdulikan kepedulian orang lain".

\section{E. Analisis Perspektif Hukum Islam terhadap Praktik Jual Beli Kambing dengan System Trade In \\ a. Analisis Metode Burhani}

Jual beli merupakan transaksi yang cukup diperhatikan dalam Islam, adapun syarat-syarat yang harus diperhatikan oleh seorang muslim sebelum melakukan transaksi jual beli yaitu (1) barang yang diperjualbelikan bukan barang yang gharar (penipuan), riba, dan tidak cacat. Jadi barang yang diperjualbelikan harus barang yang benar-benar diketahui halalnya, kalau semisal barang yang diperjualbelikan ternyata ada kecacatan maka si penjual harus mengatakan dengan jujur kepada si pembeli karena kecacatan nantinya akan merugikan pembeli dan jika penjual tidak mengatakan sedemikian rupa kepada pembeli maka dalam transaksi jual beli sudah tidak sah karena ada unsur penipuan di dalamnya, (2) harus ada kesepakatan oleh kedua belah pihak, jadi sebelum transaksi jual beli dilakukan maka kedua belah pihak harus melakukan kesepakatan mengenai harga, kondisi barang, dan system pembayaran, (3) setelah itu baru melakukan ijab qabul atau serah terima barang antara penjual dengan pembeli, jika barang sudah dilakukan serah terima berarti kedua belah pihak sudah sepakat dengan apapun kondisi barangnya, berapapun harganya, dan seperti apa system pembayarannya. Hal itu sejalan dengan yang diungkapkan oleh bapak Dian Berkah:

"Syaratnya kalau kita jual beli dalam syariah itu kan pasti (1) barangnya tidak boleh gharar, gharar itu barangnya tidak ada kejelasan, jenis, status, perolehan kan gitu, (2) barang itu dipastikan halal yah, halal itu berarti nggak gharar, tidak maisir, tidak dijadikan sebagai obyek judi kan gitu, kemudian ya haramlah, bukan barang yang haram. Jadi Maghrib dek, maisir, kemudian haram, gharar, gitu kan ya. Makanya tadi salah satu syarat dari jual beli ya barangnya harus halal. Halal berarti apa? Ya tidak gharar, tidak haram kan gitu kan, kemudian tidak maisir, dan dijadikan sebagai obyek untuk judi, bisa juga misalnya barang-barang yang bukan diperuntukkan sesembahan kan ada kadang-kadangkan kambing untuk sesembahan tiba-tiba kemudian nggak diketahui dijadikan obyek untuk jual beli kan nggak boleh itu, nah itu, itu makna dari halal tadi itu ya, kemudian tidak cacat, (3) harus betul-betul diadakan kesepakatan, (4) ijab dan qabul, nah diantara kedua belah pihak antara penjual dan pembeli mereka betul-betul mengetahui kadar nilai dari kambing itu."

Alasan diadakannya akad dalam transaksi jual beli adalah untuk mencegah terjadinya perselisihan diantara manusia, menjaga pihak-pihak yang ingin melakukan akad, dan menghilangkan sifat gharar (penipuan). Sehingga apabila syarat dalam transaksi jual beli itu tidak sesuai maka bisa jadi transaksi jual beli yang terjadi tidak sah, sedangkan apabila syarat dalam 
transaksi jual beli itu sudah sesuai maka transaksi jual beli yang terjadi merupakan transaksi jual beli yang dihalalkan dalam Islam.

Praktik jual beli kambing dengan system trade in yang terjadi di Desa Ketanen yaitu contohnya misal si A memiliki kambing yang harganya Rp700.000, tapi si A ingin membeli kambingnya kambing yang lebih bagus dari kambing yang dimilikinya, lalu si A menukarkan kambingnya dengan kambing milik si B yang harganya Rp1.500.000, maka saat melakukan pertukaran kambing si A dan si B akan ada selisih harga senilai Rp500.000 yang nantinya harus ditambahkan si A untuk menutupi kekurangan dari nilai kambingnya. Hal ini sejalan dengan yang di ungkapkan oleh Bapak Suyakip dan Bapak Dian Berkah:

"Jual beli tukar tambah iku praktek'e iku biasae iku ndelok kondisi fisik.e kambinge mau, kadang iku onok fisik.e kambinge kurang apik terus engko tukar seng apik kadangkan engko iso tambah."

"Jual beli tukar tambah itu praktiknya biasanya dilihat dari kondisi fisik kambing, kadang ada fisik kambing yang kurang bagus ditukar dengan yang bagus nanti selisihnya harganya bisa ditambah."

Sedangkan menurut Bapak Dian Berkah:

"Jadi gini, yang jelas kalau kita melihat perdagangan dalam Islam sudah pasti kita mengenal istilah yang namanya barter, kalau barter nilai A dengan nilai $\mathrm{B}$ dia sama, nah dalam perjalanan kita sudah tidak sebarter, sistem jual beli antara barang dengan uang. Nah sekarang harus digabung barternya ada uangnya ada. Contoh misalnya, saya pengen menukar kambing saya dengan kambing yang B, nah B itu setelah saya hitung nilainya Rp2.000.000, kambing saya nilainya Rp1.500.000, nah biar dia unsurnya sama maka saya tambah Rp500.000, jadi buar Rp2.000.000 - Rp2.000.000.”

Kambing merupakan hewan yang sangat populer dimasyarakat, karena selain sapi kambing juga merupakan hewan yang banyak sekali diperdagangkan pada saat hari raya Idul Adha, akan tetapi di Desa Ketanen jual beli kambing tidak hanya berlaku pada hari raya saja, tapi dihari-hari biasa juga sering terjadi transaksi jual beli kambing. System yang digunakan dalam transaksi jual beli kambing juga bermacam-macam, diantaranya yaitu: (1) transaksi jual beli dengan cara tunai, (2) transaksi jual beli dengan cara kredit dan (3) transaksi jual beli dengan system trade in. semua bentuk transaksinya tergantung pada penjanjian kedua belah pihak, apakah transaksi jual beli tersebut dilakukan dengan cara tunai, atau dilakukan dengan cara kredit, atau malah dilakukan dengan system trade in.

Masyarakat Desa Ketanen sangat suka berinvestasi lewat hewan peliharaan, alasannya karena investasi dengan hewan peliharaan nilai yang di peroleh tidak akan berkurang tapi akan terus bertambah selama berjalannya waktu. Misalnya saja si A membeli kambing betina yang kwalitasnya sedang dengan harga Rp800.000, setelah berjalannya waktu si kambing betina memiliki 2 ekor anak yaitu kambing laki-laki dan kambing perempuan, lalu setelah bertahun-tahun dan kambing itu timbuh menjadi kambing yang besar si A menjual 2 ekor anak kambingnya, dan kisaran uang yang dia peroleh untuk kambing yang laki-laki adalah senilai Rp1.500.000 sedangkan untuk kambing yang perempuan adalah senilai Rp800.000. Jadi dalam penjualan itu si A sudah mendapatkan untung kurang lebih sebesar Rp1.000.000 itu sudah di potong sama dedek buat minumnya kambing, sedangkan saat melakukan 
transaksi yang pertama modal dia sudah kembali, dan anak-anak betina selebihnya sudah menjadi keuntungan buat si A, tidak lagi ada modal di dalamnya, hanya saja nanti ke potong sama kebutuhan yang dibuat minum kambing. sedangkan jika kambing yang dijual adalah kambing yang kwalitasnya bagus, maka hasil yang diperoleh juga sangat bagus, karena kambing yang kwalitasnya bagus, kisaran harga untuk kambing jantan adalah Rp2.000.000 - Rp2.500.000, sedangkan untuk kambing betina adalah Rp1.000.000 - Rp1.500.000.

Contoh:

Pada tahun 2018 si B (seorang pedagang kambing) memiliki kambing yang harganya RP2.000.000 kemudian si A ingin membeli kambing si B, dengan catatan pembayaran dilakukan dengan cara tukar tambah (tarde in), pada saat itu si A memiliki kambing yang harganya Rp1.200.000. Maka pencatatan jurnal akuntansi yang dilakukan oleh si B yaitu sebagai berikut:

Harga jual kambing kwalitas bagus $=$ Rp2.000.000

Persediaan barang dagang (kurang bagus) $\quad=\mathrm{Rp} 1.200 .000-$

Kelebihan yang harus dibayarkan

(Jurnal untuk mencatat penjualan)

Kas

$=\operatorname{Rp} 800.000$

Persediaan Barang Dagang (kurang bagus) Rpo0.000

Rp800.000

Penjualan

Rp2.000.000

Harga pokok penjualan $=80 \% \times \mathrm{Rp} 2.000 .000=\mathrm{Rp} 1.600 .000$

(Jurnal untuk mencatat Hpp)

Hpp

Rp1.600.000

Persediaan Barang Dagang (bagus)

Rp1.600.000

(Perhitungan realisasi laba kotor pada transaksi di atas)

$\begin{array}{ll}\text { Harga Jual } & =R p 2.000 .000 \\ \text { Hpp: } 80 \% \text { x } 2.000 .000 & =R p 1.600 .000 \\ \text { Laba Kotor } & =R p 400.000\end{array}$

Jadi dari contoh pencatatan jurnal akuntansi di atas dapat di ketahui bahwa laba kotor yang di peroleh si B adalah sebesar Rp400.000 jika dalam satu bulan si B dapat melakukan penjulan kambing sebanyak 10 ekor dengan harga yang sama atau setiap penjualan memperoleh laba kotor yang sama, maka dalam satu bulan laba kotor yang diperoleh oleh si B adalah sebesar Rp4.000.000, dan jika penjualan tersebut berjalan sampai dengan satu tahun maka laba kotor dalam setahun adalah sebesar Rp48.000.000.

Sedangkan untuk kwalitas kambing yang dapat mempengaruhi harga dapat dilihat dari jenisnya, jika kambing itu jenisnya domba maka kwalitas yang mempengaruhi adalah warna, postur tubuh, kesehatan, ekor, dan punggung. Sedangkan jika jenis kambingnya kambing jawa atau etawa maka kwalitas kambing yang dapat mempengaruhi harga adalah dilihat dari warna, telinga, postur tubuh dan pasungan kepala. Seperti yang diuangkapkan oleh Bapak K:

"Kambing domba iku di delok teko postur tubuhe, ekore, punggunge. Tapi lek kambing jowo, etawa iku gak iso didelok teko punggunge, tapi didelok teko dowo gak.e kupinge, dowo gak.e postur tubuhe, pasungan kepalae." 
"Kambing domba itu dilihat dari postur tubuhnya, ekornya, dan punggungnya. Tapi kalau kambing jawa, etawa itu gak bisa dilihat dari punggungnya, tapi dilihat dari panjang pendeknya telinga, panjang pendeknya postur tubuh, dan pasungan di kepalanya."

Pedagang dan penyalur jual beli kambing tidak selalu menyediakan kambing yang diinginkan oleh pelanggan, kalau ternyata kwalitas yang di inginkan pelanggan tidak tersedia maka si pedagang akan mencarikannya dulu di pasar hewan. Tapi jika transaksi jual beli yang dilakukan adalah dengan system trade in, maka biasanya si pedagang akan membawa kambing pelanggan yang mau ditukarkan, dan si pedagang akan menukarkan kambingnya di pasar hewan. Seperti yang di ungkapkan oleh bapak Suyakip:

"Tergantung.. tergantung perjanjian.e kadang yo onok seng digowo disek teros egko nek wes payu di olehno maneh engko karek tambah piro. Kadang yo langsung engko, karek langsung tambah piro ngunu."

"Tergantung, tergantung dari perjanjiannya, kadang ada yang di bawa dulu kambingnya baru nanti kalau sudah laku baru di belikan kambing yang diinginkan pembeli, nanti tinggal bayar kekurangannya. Kadang ya langsung tukar tambah nanti, tinggal nambah kekurangannya."

Sejatinya perjanjian itu sangatlah penting dalam sebuah transaksi, jika perjanjiannya rusak ya selebihnya akan rusak, tapi kalau perjanjiannya baik selebihnya akan berakhir baik. Maka dari itu seorang muslim harus benarbenar hati-hati dalam memperhatikan sebuah akad dalam jual beli, jangan sampai akad yang dilakukan dalam transaksi jual beli justru mengantarkannya kedalam sebuah transaksi yang di haramkan oleh Islam.

Berdasarkan jawaban dari informan, bahwa informan memahami jual beli dengan system trade in merupakan jual beli yang hampir sama dengan dengan system barter yang mengalami perkembangan yaitu pertukaran barang dengan barang dan uang. Barter merupakan jual beli yang dilakukan dengan cara menukarkan barang dengan barang yang nominalnya sama. Sedangkan trade in merupakan pertukaran antara barang dengan barang yang nominalnya tidak sama, jadi dari pertukaran barang dengan barang ada selisih harga yang harus ditambahkan. Seperti yang dikatakan oleh bapak Dian:

"Jadi gini, yang jelas kalau kita melihat perdagangan dalam Islam sudah pasti kita mengenal istilah yang namanya barter, kalau barter nilai A dengan nilai B dia sama, nah dalam perjalanan kita sudah tidak sebarter, sistem jual beli antara barang dengan uang. Nah sekarang kasus itu digabungkan barternya ada uangnya ada."

Adapula hadist yang menjelaskan mengenai tukar tambah kurma, yaitu "Ada seorang amil zakat yang diangkat nabi untuk Daerah Khaibar dan orang itu menukarkan kurma yang bagus satu sa' dengan dua sa' kurma yang tidak bagus, dan nabi melarang transaksi semacam ini, nabi Muhammad Saw menyuruh seorang amil zakat tersebut menjualnya dulu kurma yang kurang bagus dengan dirham, baru kemudian membeli kurma yang bagus itu dengan dirham hasil penjualnnya (Salafi, 2006:283). Hadist tersebut menjelaskan bahwa transaksi jual beli kurma dengan cara tukar tambah tidak diperbolehkan, kecuali jika pada saat melakukan transaksi yang pertama kurmanya ditukar dengan dirham dulu barulah membeli kurma yang bagus 
dengan dirham. Sedangkan menurut informan transaksi jual beli kurma tidak sama dengan transaksi jual beli kambing. Berikut adalah pernyataan dari bapak Dian Berkah:

"Tukar tambah yang nilainya tidak sejenis, yah jadi itu kan kurma yang tidak bagus lah kalau ini kan kambing bukan nggak bagus. Barang itu gharar makanya nggak boleh, harus nilai yang kurma itu yang nilainya super ya ditukar dengan yang super. Kalau dia nilainya super satu nggak super ya harus menambah kekurangannya, makanya tadi kambing itu boleh menambah, ya memang harus begitu, bukan boleh harus menambah agar nilai kambing itu sama."

Jual beli antara kurma dan kambing tidaklah sama meskipun kedua transaksi jual beli tersebut melakukan transaksi dengan system yang sama. Karena yang melatar belakangi sebuah transaksi jual beli adalah bukan pada system transaksinya, melainkan pada akad jual belinya, apakah dalam melakukan akad ada unsur penipuan (gharar), atau dalam akad ternyata barang yang diperjual belikan itu riba. Tidak semua memberi tambahan itu termasuk riba, tapi yang harus perhatikan terlebih dahulu adalah apakah tambahan itu sifatnya untuk menambah nilai suatu barang atau tambahan hanya untuk keuntungan sebelah pihak, kalau untuk menambah kekurangan nilai suatu barang maka hal itu di perbolehkan, tapi jika hanya untuk keuntungan sebelah pihak maka hal itu tidak diperbolehkan dalam Islam.

\section{b. Analisis Metode Bayani}

Muslich (2013:177) jual beli merupakan akad mu'awadhah, yakni akad yang dilakukan oleh dua pihak, di mana pihak pertama menyerahkan barang dan pihak kedua menyerahkan imbalan, baik berupa uang maupun barang. Seperti pada surat At-Taubah ayat 111 yang artinya:

"Sesungguhnya, Allah telah membeli dari orang-orang mu'min, diri dan harta mereka dengan memberikan surga (sebagai balasan) untuk mereka. Mereka berperang pada jalan Allah, lalu mereka membunuh atau terbunuh. (Itu telah menjadi) janji yang benar dari Allah di dalam Taurat, Injil dan al-Qur'an. Dan siapakah yang lebih menepati janjinya (selain) daripada Allah? Maka bergembiralah dengan jual beli yang telah kamu lakukan itu, dan itulah kemenangan yang besar." (QS. AtTaubah: 111).

Ayat itu menjelaskan bahwa selama ini Allah telah melakukan transaksi jual beli dengan seorang mu'min, yaitu dengan cara Dia membeli harta benda kaum mukmin dan membayarnya dengan surga-Nya. Hal ini bisa membuat kaum muslimin untuk berlomba-lomba dalam berjihad, karena ayat tersebut menggambarkan sebuah transaksi yang keuntungannya sangat besar bagi manusia. Pengorbanan yang telah mereka berikan berupa harta benda dan jiwa raga yang akan ditukar dengan sesuatu yang sangat berharga, yang tak pernah dilihat oleh mata manusia, dan tak pernah didengar oleh telinga mnusia, dan nilai-nilainya jauh lebih tinggi daripada harta benda. Selain itu jual beli yang terjadi antara Allah dan kaum Muslimun ini tidak akan pernah dibatalkan. Tidak seperti jual beli antara manusia yang satu dengan manusia yang lain, yang cenderung mereka bisa membatalkan sebah transaksi jual beli jika akadnya tidak sesuai.

Salafi (2006:282) Dari Abu Hurairah ra., Rasulullah saw bersabda: "Diperbolehkan menjaul emas dengan emas yang sama timbangannya dan sebanding, dan perak dengan perak yang sama timbangannya dan sebanding, 
barang siapa yang menambah atau meminta tambahan, maka itu adalah riba." (HR. Muslim). Sedangkan menurut bapak Dian:

"Yang jelas semua ditetapkan secara umum kalau kita mau kembali kepada proses bisnis kembali kembali pada ayat "Wa-ahalla allahu albay'a waharrama alrriba" agar dia nggak riba maka ditarik kepada jual beli, maka muncul akad, Nah jadikan nanti dia jual beli barter jadikan akad ada perjanjian, akad itu betul-betul "ini kita sudah jual loh ya dengan barter"."

Makna yang terkandung dalam QS. Al-Baqarah ayat 275: (1) Allah telah menghalalkan transaksi jual beli, (2) Allah telah mengharamkan memakan riba, (3) manusia tidak perlu takut kehilangan harta sehingga melakukan transaksi yang dilarang oleh Allah, karena yang memberi rejeki adalah Allah, (4) jika kamu masih takut dengan rejeki yang kurang maka bersedekahlah supaya rejeki kamu digandakan oleh-Nya, (5) ancaman bagi orang yang tetap memakan riba padahal sudah datang peringatan Allah, maka ancaman bagi orang itu adalah sebagai penghuni neraka selamanya.

Proses bisnis dalam Islam tidaklah mudah, yang terpenting ikuti aturan Hukum berdagang dalam Islam, supaya pembisnis tidak terjerumus dalam transaksi yang haram. Jual beli adalah transaksi yang saling menguntungkan antara penjual dan pembeli, dalam transaksi jual beli hakhak penjual dan pembeli harus ditepati. Jangan karna terlalu terlena dengan dunia dan terlalu terlena dengan harta sampai kita melakukan sebuah transaksi jual beli yang merugikan orang lain. Jika ingin harta betambah maka perbanyak shodaqah, infaq, dan zakat, jangan memakan hak orang lain. Seperti makna yang terkandung dalam QS. At-Taubah ayat 24 dan ayat 34 yaitu sebagai berikut:

Makna yang terkanadung dalam QS. At-Taubah ayat 24, diantaranya yaitu: (1) Jika orang yang kamu sayangi dan kamu hormati lebih mencintai kekafiran daripada keimanan maka tinggalkanlah, (2) Allah mengancam orang yang lebih mementingkan keluarga, kerabat, dan sanak familinya daripada Allah dan Rasul-Nya serta berjihad di jalan-Nya, (3) Allah melarang orang yang lebih mecintai harta daripada Allah dan Rasul-Nya serta berjihad di jalan-Nya, (4) Allah melarang orang yang lebih mengkhawatirkan kerugian dari perniagaan yang diusahakan, daripada mengkhawatirkan urusan akhirat, sesungguhnya keuntungan dan harta sudah diatur dengan sangat baik oleh Allah SWT, (5) Jika manusia lebih mencintai Allah dan Rasul-Nya serta berjihad di jalan-Nya sesungguhnya Allah akan memberi kecukupan dalam hidupnya, dan Allah akan memberi berkah selama perjalanan hidupnya.

Sedangkan Makna yang terkanadung dalam QS. At-Taubah ayat 34, diantaranya yaitu: (1) Allah memperingati hamba-hamba-Nya yang beriman supaya tidak mengikuti berbuatan orang-orang Yahudi dan orang-orang Nasrani yang mengambil dan menggunakan harta orang lain dengan cara yang tidak benar, (2) Orang-orang Yahudi dan rahib-rahib Nasrani menghalangi manusia dari jalan Allah yang lurus dengan berbagai cara yaitu khotbah, ceramah, dan penafsiran yang mereka ajarkan yang telah mereka selewengkan dari dasar pijakannya, yang mereka rubah sesuai dengan kepentingan mereka sendiri, (3) Allah memerintahkan kepada orang-orang muslim agar slalu waspada untuk menghindari dan tidak meniru keburukankeburukan orang-orang Yahudi dan Nasrani, (4) Orang-orang yang menyimpan emas dan perak dan tidak mau menafkahkannya pada jalan Allah, seperti zakat, infaq, dan shadaqah, maka mereka akan mendapat siksa 
yang sangat pedih, (5) Hendaklah kita berhati-hati dalam masalah harta, dan wajib bagi umat Islam belajar mengelola harta secara baik dan benar, (6) Sesungguhnya harta bisa menjadikan kita masuk surga atau neraka tergantung cara pengelolaan kita terhadap harta tersebut.

\section{SIMPULAN}

Hasil Akhir dalam penelitian ini menyimpulkan bahwa kualitas kambing yang bisa mempengaruhi harga dapat dilihat dari jenisnya, jika kambing itu jenisnya domba maka yang dapat mempengaruhi adalah corak, postur tubuh, ekor, dan punggung. Sedangkan jika kambing itu jenisnya jawa atau etawa maka dapat dilihat dari panjang pendeknya tekinga, panjang pendeknya postur tubuh, dan pasungan dikepalanya. Transaksi jual beli kambing dengan system trade in (tukar tambah) di Desa Ketanen menurut Bapak Dian Berkah diperbolehkan dalam hukum Islam, karena dalam melakukan transaksi jual beli kambing dengan system trade in (tukar tambah) tidak ada unsur gharar didalamnya atau penipuan masalah harga. Transaksi jual beli kambing dengan system trade in (tukar tambah) akan diperbolehkan atau akan menjadi halal dengan syarat nilai kambing itu diketahui oleh kedua belah pihak sehingga tidak ada nilai barang yang gharar, harus diadakan kesepakatan oleh kedua belah pihak, dan kambing yang diperjual belikan harus kambing yang halal. Seperti makna yang terdapat dalam surat AlBaqarah ayat 275 bahwa Allah sudah menghalalkan jual beli dan mengharamkan riba, jadi jual beli tidak ada yang haram kecuali jika dalam transaksi jual beli ada unsur riba didalamnya, karena Allah sudah memperingatkan bahwa orang-orang yang memakan riba padahal sudah datang peringatan dari tuhannya maka akan menjadi penghuni neraka yang kekal didalamnya.

\section{REFERENSI}

Ahmad, M. (2013). Psikologi Agama dalam Perspektif Epistemologi Bayani, Burhani, dan Irfani. Jurnal Penelitian, 6(1).

Arifin, B. (1996). Pelembagaan hukum Islam di Indonesia: akar sejarah, hambatan, dan prospeknya. Gema Insani.

Azzam, P. D. A. A. M. (2014). Fiqh Muamalat (Sistem Transaksi dalam Figh Islam), Terjemahan Nadirsyah Hawari, Lc, M.A. Jakarta: AMZAH.

Bahri, S. (2013). Hukum Promosi Produk Dalam Perspektif Hukum Islam. Episteme: Jurnal Pengembangan Ilmu Keislaman, 8(1), 135-154.

Departemen Agama RI. (2004). Al-Qur'an dan Terjemahnya, Bandung: CV Penerbit Jumanatul 'Ali-Art.

Emzir. (2016). Metodologi Penelitian Kualitatif (Analisis Data). Jakarta: Rajawali Pers.

Fadhilah, N. (2015). Jual beli perhiasan emas dengan cara tukar tambah di Toko Emas Enggal Pasar Pakisaji Kabupaten Malang: Studi komparasi empat madzhab (Doctoral dissertation, Universitas Islan Negeri Maulana Malik Ibrahim).

Ibrahim, D. (2014). Metodologi Penelitian dalam Kajian Islam (Suatu Upaya Iktisyaf Metode-Metode Muslim Klasik). Intizar, 20(2), 247-266.

Lutfi, A. (2017). Studi Perbandingan Model Ilmu Nalar Bayani dan Nalar Burhani. Dialogia, 15(1), 95-114. 
Makiah, Z. (2014). Epistemologi Bayani, Burhani dan Irfani dalam Memperoleh Pengetahuan Tentang Mashlahah. Syariah: Jurnal Hukum dan Pemikiran, 14(2).

Mujiatun, S. (2014). Jual Beli dalam Perspektif Islam: Salam dan Istisna'. JRAB: Jurnal Riset Akuntansi \& Bisnis, 13(2).

Mulyana, A. (2018). Pengaruh Penjualan dan Biaya Produksi terhadap Laba Usaha pada PT Mayora Indah, Tbk Tahun 2009-2015. E-Jurnal STIE INABA, 17(2), 228-256.

Muslich, A. W. (2010). Fiqh Muamalat. Jakarta: AMZAH.

Muzakki, M. H., \& Nurhayati, S. (2016). Tinjauan Hukum Islam tentang Praktik Jual Beli Sayur Melalui Wakâlah di Desa Krisik Ponorogo. ISLAMICA: Jurnal Studi Keislaman, 10(2), 522-543.

Nata, Abdullah. (2004). Metodologi Studi Islam. Jakarta: PT Raja Grafindo Persada.

Nugrahani, F., dan Hum, M. (2014). Metode Penelitian Kualitatif. Solo: Cakra Books.

Ridwan, A. H. (2016). Kritik Nalar Arab: Eksposisi Epistemologi Bayani, 'Irfani dan Burhani Muhammad Abed Al-Jabiri. Afkaruna: Indonesian Interdisciplinary Journal of Islamic Studies, 12(2), 187-222.

Salafi, D. M. L. A. (2006). Syarah Bulughul Maram, Terjemah Achmad Sunarto. Surabaya: Karya Utama.

Santoso, S. (2014). Perspektif Hukum Islam Terhadap Kitab undang-undang Hukum (KUH) Perdata Pasal 1467 Tentang Larangan Jual Beli Antara Suami Istri. Jurnal Penelitian, 8(2).

Shobirin, S. (2016). Jual Beli Dalam Pandangan Islam. Bisnis: Jurnal Bisnis dan Manajemen Islam, 3(2), 239-261.

Siswadi, S. (2015). Lembaga Keuangan Syari'ah Non Bank BMT (Baitul Mal Wat Tamwil) Tawaran Bebas Aqad Yang Dilarang Dalam Syari'at Islam. Ummul Quro, 6(2), 74-93.

Sudarminta. (2002). Epistemologi Dasar. Yogyakarta: KANISIUS (Anggota IKAPI).

Sugiyono. (2013). Memahami Penelitian Kualitatif. Bandung: CV. ALFABETA.

Sukardi, D., \& Maesaroh, S. (2018). Multi Level Marketing PT. Harmoni Dinamik Indonesia Cabang Cirebon Dalam Perspektif Hukum Islam dan Hukum Positif. Al-Mustashfa: Jurnal Penelitian Hukum Ekonomi Syariah, 3(1), 85-99.

Yunus, M., Hamdani, F. F. R. S., dan Shofia, G. K. (2018). "Tinjauan Fikih Muamalah Terhadap Akad Jual Beli Dalam Transaksi Online Pada Aplikasi Go-Food". Amwaluna, 2(1), 135-146. 